\title{
Ocena wyników badań złączy spawanych techniką phased array wg PN-EN ISO 19285
}

\author{
Evaluation of phased array test results of welded joints \\ according to PN-EN ISO 19285
}

\section{Streszczenie}

W pracy przedstawiono sposób oceny wskazań wykrytych w badaniach złączy spawanych techniką phased array na podstawie PN-EN ISO 19285. Przedstawiono ocenę i klasyfikację wskazań bazującą na długości i wysokości, którą uzupełniono licznymi przykładami. Omówiono również ocenę bazującą na długości i amplitudzie wskazań oraz przedyskutowano zasadność stosowania tego wariantu oceny. Artykuł kierowany jest do personelu badań nieniszczących oraz personelu spawalniczego, zainteresowanego tematyką nowoczesnych technik badań ultradźwiękowych.

Słowa kluczowe: badania nieniszczące; badania ultradźwiękowe spoin; technika phased array

\begin{abstract}
The paper presents a method of evaluating indications detected in the studies of welded joints using the phased array technique based on PN-EN ISO 19285. The evaluation and classification of indications based on their length and height, which was supplemented with numerous examples, was presented. An assessment based on the length and amplitude of the indications was discussed and the validity of the use of this evaluation variant was discussed. The article is addressed to non-destructive testing and welding personnel interested in the subject of advanced ultrasonic testing techniques.
\end{abstract}

Keywords: nondestructive testing; ultrasonic testing of welds; phased array technique

\section{Wstęp}

Badania złączy spawanych ultradźwiękową techniką phased array zostały znormalizowane zarówno w aspekcie wykonawstwa, jak i oceny wyników badań. Zasady stosowania badań phased array $\mathrm{w}$ odniesieniu do złączy spawanych o grubości równej lub większej od $6 \mathrm{~mm}$ opisano w PN-EN ISO 13588 wydanej w 2013 r. [2,5]. Jednakże mimo upływu kilku lat od wprowadzenia tejże normy, stopień wdrożenia badań phased array do polskiego przemysłu jest niewielki w stosunku do zalet i możliwości badawczych, jakie stwarza ta technika badań ultradźwiękowych. Od wielu lat zauważalny jest wzrost stosowania konwencjonalnych badań ultradźwiękowych, jednakże nie towarzyszył mu dotychczas analogiczny wzrost stosowania badań phased array, mimo że mogą one $z$ powodzeniem zastąpić je w większości zastosowań dotyczących badania złączy spawanych. Rezygnacja z badań konwencjonalnych na rzecz techniki phased array nie tylko zwiększa prawdopodobieństwo wykrycia nieciągłości, ale również zwiększa wiarygodność badania, między innymi dzięki zapisowi "surowych" wyników badań, jakimi są pliki danych z defektoskopu. Stanowią one obiektywny obraz wskazań uzyskanych w badanym złączu spawanym, zawierający zarówno wskazania istotne (pochodzące od nieciągłości), jak i wskazania pochodzące od geometrii badanego złącza [1]. Obserwacja wskazań na graficznych zobrazowaniach daje znacznie większe możliwości szybkiej i poprawnej identyfikacji i klasyfikacji wskazań fałszywych, których interpretacja jest największym problemem w badaniach konwencjonalnych. Ponadto, dzięki zapisowi wszystkich danych możliwa jest wielokrotna weryfikacja poprawności wyników kontroli badanego złącza, bez potrzeby powtórnego wykonania badań.

Istnieje wiele czynników wpływających na dotychczasowy niewielki wzrost zastosowań techniki phased array w Polsce. Są nimi między innymi duża złożoność systemów badań i związane z tym znacznie większe wymagania w zakresie kompetencji niezbędnych do prawidłowego zaplanowania strategii badań oraz dokonania ustawień i kalibracji systemu, które to czynności zgodnie z PN-EN ISO 13588 muszą być wykonywane na podstawie pisemnej procedury badania, a ich skuteczności musi być weryfikowana przy pomocy specjalnie wykonanych próbek odniesienia. Ponadto dużym ograniczeniem, zwłaszcza dla mniejszych laboratoriów, były dotychczas koszty wyposażenia do badań phased array, kilkukrotnie przekraczające ceny zestawów do badań konwencjonalnych.

Mgr inż. Rafał Kaczmarek - Politechnika Częstochowska, dr inż. Karol Kaczmarek - Instytut Spawalnictwa.

Autor korespondencyjny/Corresponding author. rafal.kaczmarek133@gmail.com 
Jednak kluczowym czynnikiem ograniczającym szybkość procesu wdrażania techniki phased array jest z pewnością niewystarczająca znajomość tej techniki w środowisku personelu NDT, spawalników, inspektorów nadzoru czy klientów laboratoriów badawczych. Naturalnym jest, iż znacznie chętniej są stosowane metody dobrze znane i ugruntowane w przemyśle, takie jak badania radiograficzne czy konwencjonalne badania ultradźwiękowe. W przypadku chęci zastąpienia ich innowacyjnymi technikami badań często występuje duża nieufność w stosunku do nowej, skomplikowanej techniki badawczej, dotychczas rzadko stosowanej w polskim przemyśle. Fakt ten pogłębiał brak przepisów normatywnych regulujących kwestię poziomów akceptacji dla złączy spawanych, który wymuszał opracowanie i przyjęcie, na podstawie uzgodnienia między stronami umowy, kryteriów akceptacji dla danego zadania badawczego. Nie zawsze jednak strony umowy były skłonne do zaakceptowania tego rozwiązania.

Z tego względu ukazanie się w drugiej połowie 2017 roku PN-EN ISO 19285 dotyczącej kryteriów oceny znacznie ułatwiło proces wdrażania badań phased array [6]. Norma ta odnosi się do oceny wskazań sklasyfikowanych zgodnie z PN-EN ISO 13588 i wprowadza poziomy akceptacji dedykowane dla odpowiednich poziomów jakości złączy spawanych. Zaproponowane poziomy akceptacji i ich korelacja z odpowiednimi poziomami jakości została także uwzględniona w najnowszym wydaniu PN-EN ISO 17635.

W pracy przedstawiono sposoby oceny wskazań wykrytych w badaniach złączy spawanych techniką phased array na podstawie PN-EN ISO 19285. Ma ona na celu zapoznanie Czytelników z oceną wskazań zaproponowaną w wyżej wymienionej normie międzynarodowej i tym samym, ułatwienie procesu wdrażania badań phased array do kontroli jakości złączy spawanych.

\section{Poziomy akceptacji wg PN-EN ISO 19285}

W normie PN-EN ISO 19285 określono trzy poziomy akceptacji. Korelacje między poziomami jakości, poziomami badania i poziomami akceptacji przedstawiono w tablicy I.

Dla poziomów akceptacji 2 i 3 może być stosowany jeden z dwóch, równorzędnych sposobów oceny wskazań:

- na podstawie długości i wysokości wskazań,

- na podstawie długości i amplitudy wskazań.

Pierwszy sposób, oparty na długości i wysokości wskazań, jest analogiczny do oceny stosowanej w badaniach techniką TOFD na podstawie PN-EN ISO 15626 [7]. Polega on na pomiarze i porównaniu wysokości wykrytych wskazań z wymiarem dopuszczalnym, a następnie na określeniu skumulowanej długości wskazań akceptowalnych, a także sumy wskazań punktowych na określonym odcinku złącza.

Tablica I. Poziomy akceptacji dla techniki Phased Array Table I. Acceptance levels for the Phased Array technique

\begin{tabular}{|c|c|c|}
\hline $\begin{array}{c}\text { Poziom jakości } \\
\text { zgodnie z ISO 5817 }\end{array}$ & $\begin{array}{c}\text { Poziom } \\
\text { badania zgodnie } \\
\text { z ISO 13588 }\end{array}$ & $\begin{array}{c}\text { Poziom } \\
\text { akceptacji }\end{array}$ \\
\hline C, D & A & 3 \\
\hline B & B & 2 \\
\hline według uzgodnienia & C & 1 \\
\hline zastosowania specjalne & D & $\begin{array}{c}\text { według } \\
\text { uzgodnienia }\end{array}$ \\
\hline
\end{tabular}

Kryteria akceptacji dla poziomu akceptacji 1 są określone wyłącznie dla oceny bazującej na długości i wysokości
W przypadku drugiego sposobu, opartego na długości i maksymalnej amplitudzie wskazań, ocena jest analogiczna do tej, która jest stosowana w konwencjonalnych badaniach ultradźwiękowych na podstawie PN-EN ISO 11666 [8]. W pierwszym kroku amplitudy poszczególnych wskazań przyrównywane są do dopuszczalnej wartości granicznej (w decybelach), których wartość jest uzależniona od długości wskazania. W kolejnym etapie obliczana jest skumulowana długość wskazań akceptowalnych na określonym odcinku złącza, która nie może przekroczyć dopuszczalnej wartości granicznej.

Poniżej szczegółowo przedstawiono obydwa sposoby oceny wskazań.

\section{Kryteria akceptacji bazujące na długości i wysokości}

W przypadku stosowania kryteriów wymiarowych po identyfikacji wskazań istotnych pierwszym etapem oceny jest ich klasyfikacja, mająca wspólne elementy z klasyfikacją stosowaną w badaniach TOFD [4]. Wskazania powinny być sklasyfikowane jako:

- wskazanie wychodzące na powierzchnię,

- wskazanie wewnętrzne,

- wskazanie punktowe.

Wskazania wewnętrzne oraz wychodzące na powierzchnię są wymiarowane przy pomocy kursorów pomiarowych. Zgodnie z PN-EN ISO 19285 wysokość wskazania powinna być wymiarowana przy pomocy sygnałów dyfrakcyjnych, jeśli takowe występują. Przykład wymiarowania wysokości pęknięcia z użyciem sygnałów dyfrakcyjnych pokazano na rysunku 1.

Jeśli wysokość nie może zostać zmierzona przy użyciu sygnałów dyfrakcyjnych, wówczas powinna ona zostać wyznaczona „w oparciu o amplitudę z użyciem poziomu odniesienia jak opisano w ISO 11666" [6]. Stwierdzenie to sugeruje użycie techniki ustalonego poziomu amplitudy w stosunku do poziomu oceny, służącego do wymiarowania długości wskazań. Jednakże norma pozostawia możliwość użycia innych technik wymiarowania, np. spadku $6 \mathrm{~dB}$. Rozwiązanie to wydaje się korzystniejsze z punktu widzenia dokładności wymiarowania wysokości wskazań, gdyż jest powiązane z maksymalną amplitudą wskazania, a błąd wynikający z szerokości wiązki dla mocno zogniskowanych głowic phased array jest niewielki. Ponadto, w większości dotychczasowych zastosowań techniki phased array na świecie stosowana jest technika spadku $6 \mathrm{~dB}$. Przykład wymiarowania wskazania niewykazującego sygnałów dyfrakcyjnych pokazano na rysunku 2.

Kolejnym etapem wymiarowania wskazań jest określenie ich długości. W punkcie 7.2 PN-EN ISO 19285 czytamy: „długość wskazania powinna być zmierzona jak opisano w ISO 11666, z użyciem wiązki, która zapewnia maksymalną amplitudę". Jest to więc ponowne odniesienie do techniki ustalonego poziomu amplitudy, która jest rekomendowana w ISO 11666 do wymiarowania długości wskazań. Polega ona na pomiarze odcinka, na którym amplituda wskazania osiąga lub przekracza ustalony poziom oceny. Zatem nasuwa się pytanie, czy zapis ten wskazuje tylko na technikę wymiarowania, czy także nakazuje użycie poziomu oceny takiego, jaki został określony w ISO 11666? Zdaniem autorów, druga interpretacja jest niewłaściwa, gdyż staje w sprzeczności z nakazem wymiarowania wysokości przy użyciu sygnałów dyfrakcyjnych. Sygnały te mają znacznie niższą amplitudę od sygnałów odbitych kierunkowo od nieciągłości, stąd też ich amplituda często spada poniżej poziomu oceny 


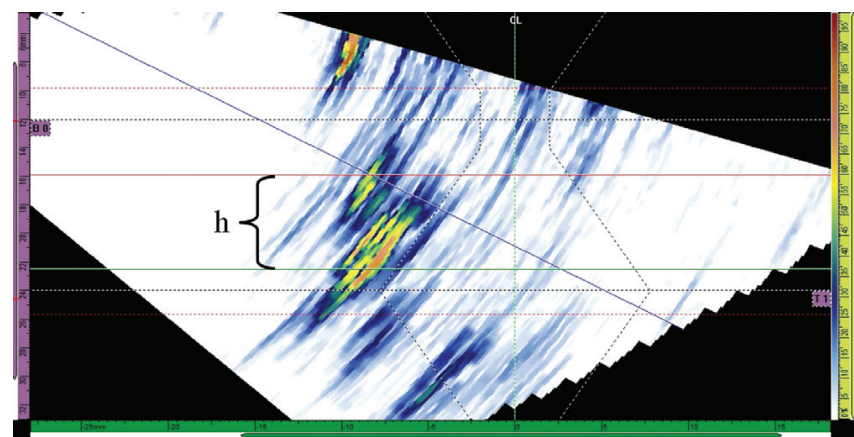

Rys. 1. Wymiarowanie wysokości h wskazania od pęknięcia usytuowanego w strefie wpływu ciepła złącza o grubości $12 \mathrm{~mm}$ przy użyciu sygnałów dyfrakcyjnych

Fig. 1. Dimensioning of the height $h$ of the indication from the crack located in the heat affected zone of the joint with a thickness of $12 \mathrm{~mm}$ using diffraction signals

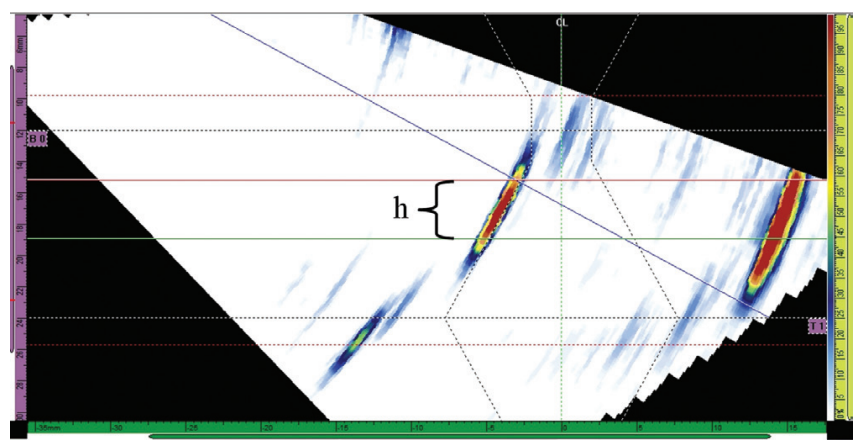

Rys. 2. Wymiarowanie spadkiem $6 \mathrm{~dB}$ wysokości h wskazania od przyklejenia brzegowego w złączu spawanym o grubości $12 \mathrm{~mm}$ Fig. 2. Dimensioning with $6 \mathrm{~dB}$ drop in the height h of the indication from edge sticking in a $12 \mathrm{~mm}$ thick welded joint

opisanego w ISO 11666 (np. $\mathrm{H}_{0}-14$ dB dla techniki 1 nastawiania poziomu odniesienia, gdzie $\mathrm{H}_{0}$ oznacza poziom odniesienia w postaci krzywej DAC od otworu cylindrycznego o średnicy $3 \mathrm{~mm}$ ). Prowadziłoby to do wyznaczenia wysokości wskazania przy pomocy sygnałów dyfrakcyjnych, którego długość wynosiłaby jednak zero ze względu na niewielką amplitudę tychże sygnałów, niższą od przyjętego poziomu oceny. Ponadto narzucenie poziomu oceny z badań konwencjonalnych jednocześnie eliminuje możliwość oceny wskazań od gniazd pęcherzy, które są wyraźnie widoczne na zobrazowaniach phased array, a których amplituda ze względu na duże rozproszenie wiązki jest zazwyczaj kilka decybeli poniżej poziomu oceny z badań konwencjonalnych. Adekwatny przykład pokazano na rysunku 3 przedstawiającym zobrazowanie typu S z miejsca występowania gniazda pęcherzy. Maksymalna amplituda wskazania wynosi $\mathrm{H}_{0}-15,7 \mathrm{~dB}$, podczas gdy poziom oceny zgodny z ISO 11666

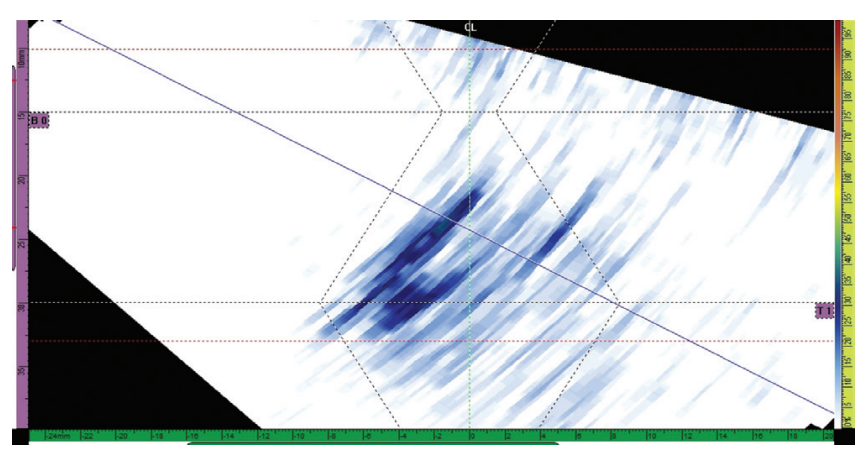

Rys. 3. Przykład dużego gniazda pęcherzy w złączu spawanym o grubości $15 \mathrm{~mm}$ o maksymalnej amplitudzie $\mathrm{H}_{0}-15,7 \mathrm{~dB}$

Fig. 3. An example of a large localized porosity in a $15 \mathrm{~mm}$ thick welded joint with a maximum amplitude of $\mathrm{H}_{0}-15,7 \mathrm{~dB}$ to $\mathrm{H}_{0}-14 \mathrm{~dB}$. W przypadku przyjęcia poziomu oceny $\mathrm{H}_{0}-14 \mathrm{~dB}$, wskazanie to nie będzie oceniane, pomimo że jest doskonale widoczne na zobrazowaniu. Należy nadmienić, że w badaniach RT to gniazdo pęcherzy jest nieakceptowane.

Stąd też, przyjęcie poziomu oceny z badań konwencjonalnych $w$ technice phased array nie powinno być stosowane, gdyż eliminuje możliwość oceny niektórych wskazań skutecznie wykrytych tą techniką badań (np. gniazda pęcherzy czy nieciągłości płaskie prostopadłe do powierzchni wykazujące wyłącznie sygnały dyfrakcyjne o niskiej amplitudzie z wierzchołków nieciągłości itd.). Z powyższych rozważań wynika, iż niniejszy zapis normy odwołujący się do ISO 11666 jest nieprecyzyjny i w kolejnych wydaniach powinien zostać uściślony, aby nie budził w przyszłości wątpliwości co do jego interpretacji.

W przypadku, gdy wskazania są zlokalizowane w niedalekiej odległości od siebie mogą podlegać grupowaniu. Następuje ono, gdy są spełnione jednocześnie dwa warunki:

- odległość pomiędzy dwoma indywidualnymi wskazaniami wzdłuż złącza jest mniejsza niż długość dłuższego ze wskazań,

- odległość pomiędzy dwoma indywidualnymi wskazaniami w kierunku grubości złącza ma wartość mniejszą niż wysokość wyższego ze wskazań.

Długość tak utworzonej grupy nie może służyć do dalszego grupowania. Grupowaniu nie podlegają wskazania punktowe.

Warto zauważyć, że powyższy sposób grupowania został zaczerpnięty wprost z normy ISO 15626 dotyczącej oceny wskazań w TOFD. Stąd też nie występuje w nim trzeci warunek grupowania, odnoszący się do odległości pomiędzy wskazaniami w kierunku szerokości spoiny (tzn. w kierunku osi y). Jest to niezrozumiałe, gdyż - w przeciwieństwie do TOFD - w przypadku techniki phased array możliwe jest wyznaczenie lokalizacji wskazań w tymże kierunku. Z tego względu nieuzasadnione jest grupowanie dwóch wskazań, których odległość w kierunku szerokości spoiny wynosi kilkanaście lub kilkadziesiąt milimetrów (np. wskazania od niewielkich nieciągłości, usytuowane na dwóch, przeciwległych ściankach rowka spawalniczego w złączu o dużej grubości). Z kolei zgodnie z amplitudowymi kryteriami akceptacji zawartymi w PN-EN ISO 19285 i omówionymi w dalszej części artykułu, wskazania takie nie są grupowane.

Po wyznaczeniu długości i wysokości wskazań (lub grupy wskazań) oraz określeniu ich klasyfikacji (wychodzące na powierzchnię, wewnętrzne) następuje przyrównanie uzyskanych wartości z wartościami granicznymi dla danego poziomu akceptacji. W tablicy II zawarto wymiarowe kryteria akceptacji dla poziomu akceptacji 2 wymaganego dla poziomu jakości B. O akceptacji wskazania decyduje wysokość, długość i rodzaj wskazania. Jak widzimy, zgodnie z regułami mechaniki pękania bardziej rygorystycznie traktowane są wskazania o większej długości oraz wychodzące na powierzchnię. Na przykład, dla grubości złącza równej $16 \mathrm{~mm}$ wskazania wewnętrzne o długości nieprzekraczającej $16 \mathrm{~mm}$ są akceptowalne do wysokości $4 \mathrm{~mm}$, natomiast wychodzące na powierzchnię do $2 \mathrm{~mm}$. Wskazania o długości powyżej $16 \mathrm{~mm}$ są akceptowalne jedynie do wysokości $1 \mathrm{~mm}$ (zarówno wewnętrzne, jak i wychodzące na powierzchnię).

Jeżeli wszystkie wykryte wskazania są akceptowalne, wówczas dokonuje się wyznaczenia skumulowanej długości wszystkich indywidualnie akceptowalnych wskazań na określonym odcinku złącza (nie wlicza się wskazań punktowych). Długość odcinka, na którym należy zsumować wskazania, zależy od grubości złącza. Na przykład, dla grubości $t \leq 50$ $\mathrm{mm}$ jego długość wynosi 12t. Skumulowana długość wskazań na tak wyznaczonym odcinku nie może przekroczyć granicznej wartości, określonej dla danego poziomu akceptacji. (Na przykład dla zakresu grubości $\mathrm{t} \leq 50 \mathrm{~mm}$ i poziomu 
Tablica II. Kryteria akceptacji dla poziomu akceptacji 2

Table II. Acceptance criteria for acceptance level 2

\begin{tabular}{|c|c|c|c|c|}
\hline \multirow[b]{2}{*}{ Zakres grubości } & \multicolumn{3}{|c|}{$\begin{array}{l}\left.\text { Maksymalna dopuszczalna długość ( } I_{\max }\right) \\
\text { jeśli } \mathrm{h}<\mathrm{h} 2 \text { lub h3 }\end{array}$} & \multirow{2}{*}{$\begin{array}{c}\text { Maksymalna } \\
\text { dopuszczalna wysokość } \\
\text { (h1) gdy I > I } \max \\
\text { h1 [mm] }\end{array}$} \\
\hline & $I_{\max }[\mathrm{mm}]$ & $\begin{array}{c}\text { wychodzące } \\
\text { na powierzchnię } \\
\text { h3 }[\mathrm{mm}]\end{array}$ & $\begin{array}{c}\text { wewnętrzne } \\
\text { h2 [mm] }\end{array}$ & \\
\hline $6 \mathrm{~mm}<\mathrm{t} \leq 15 \mathrm{~mm}$ & $\mathrm{t}$ & 2 & 2 & 1 \\
\hline $15 \mathrm{~mm}<\mathrm{t} \leq 50 \mathrm{~mm}$ & $\mathrm{t}$ & 2 & 4 & 1 \\
\hline $50 \mathrm{~mm}<\mathrm{t} \leq 100 \mathrm{~mm}$ & 50 & 3 & 5 & 2 \\
\hline $\mathrm{t}>100 \mathrm{~mm}$ & 60 & 4 & 6 & 3 \\
\hline
\end{tabular}

akceptacji 2 wartość ta wynosi 4t). W przypadku złącza o grubości t = $16 \mathrm{~mm}$, dla którego wymagany jest poziom akceptacji 2, dopuszczalna skumulowana długość wszystkich indywidualnie akceptowalnych wskazań na odcinku o długości $192 \mathrm{~mm}$ wynosi $64 \mathrm{~mm}$.

Ostatnim etapem oceny jest obliczenie ilości wskazań punktowych na odcinku o długości $150 \mathrm{~mm}$ (dla wszystkich grubości). Ilość wskazań punktowych nie może przekroczyć wartości 1,2t. Tak więc, dla złącza o grubości t $=16 \mathrm{~mm}$ na odcinku o długości $150 \mathrm{~mm}$ może występować maksymalnie 20 wskazań punktowych. Wskazania punktowe w PN-EN ISO 19285 są zdefiniowane jako wskazania nieposiadające znaczącego rozmiaru w żadnym z kierunków. Z tego względu w procedurze badania powinny zostać zawarte precyzyjne wytyczne określające zasady klasyfikacji wskazań punktowych. Powinny uwzględniać one szerokość wiązki ultradźwiękowej w kierunku długości i grubości badanego złącza, wynikającą z częstotliwości, wymiaru apertury, zastosowanego ogniskowania oraz odległości głowicy od osi spoiny. W procedurze badania powinien zostać również określony poziom rejestracji dotyczący wskazań punktowych.

\section{Kryteria akceptacji bazujące na długości i amplitudzie}

Drugi, równorzędny sposób oceny wskazań zaproponowany w PN-EN ISO 19285 jest zaczerpnięty z normy ISO 11666, dotyczącej oceny w konwencjonalnych badaniach ultradźwiękowych. Z tego względu o akceptowalności poszczególnych wskazań (lub grupy wskazań) decydują wyłącznie długość i maksymalna amplituda, a w dalszym etapie o akceptowalności całego złącza decyduje skumulowana długość wskazań akceptowalnych na określonym odcinku złącza. W tym przypadku nie występuje więc klasyfikacja wskazań, w której dokonuje się rozróżnienia na wskazania wychodzące na powierzchnię, wewnętrzne czy punktowe, jak miało to miejsce w przypadku wymiarowych kryteriów akceptacji. Kryteria amplitudowe opisano wyłącznie dla poziomów akceptacji 2 i 3 , ponadto mogą być one stosowane wyłącznie w zakresie grubości $8 \mathrm{~mm} \leq \mathrm{t}<100 \mathrm{~mm}$.

Długość wskazań jest określana poprzez pomiar odcinka wzdłuż spoiny, na którym amplituda wskazania utrzymuje się powyżej poziomu oceny, z zastosowaniem techniki ustalonego poziomu amplitudy, opisanej w załączniku B normy ISO 19285. Ponieważ poziomy odniesienia oraz poziomy oceny są tożsame z tymi, które są stosowane w badaniach konwencjonalnych, z tego względu nasuwają się tutaj te same wątpliwości, które opisano przy omawianiu pomiaru długości wskazań przy kryteriach wymiarowych. Duża część wskazań reprezentowana przez sygnały dyfrakcyjne lub sygnały odbite rozproszone (np. od gniazd pęcherzy), wykazuje amplitudę poniżej narzuconego poziomu oceny. Stąd też mogą być one wyraźnie widoczne na zobrazowaniach phased array, a mimo to nie będą oceniane z powodu niewielkiej amplitudy wskazań. Takowy sposób oceny prowadzi więc do niewykorzystania potencjału badań phased array.

Norma w odniesieniu do wyznaczania długości wskazań w przypadku stosowania kryteriów amplitudowych pozostawia możliwość zastosowania alternatywnych technik wymiarowania, jeśli takie zostały określone.

Prócz wyznaczenia długości wskazania należy także określić jego amplitudę w stosunku do poziomu odniesienia, nastawionego przy użyciu jednej z czterech technik (1 - otwory poprzeczne, 2 - otwory płaskodenne, 3 - rowek prostokątny, 4 - otwór płaskodenny dla techniki tandem).

Po wyznaczeniu długości i maksymalnej amplitudy wskazań wyznaczona wartość amplitudy zostaje przyrównana do poziomów rejestracji oraz poziomów akceptacji zgodnie z tabelą A1 zamieszczoną w aneksie A PN-EN ISO 19285. Przyjęte poziomy rejestracji i akceptacji są tożsame z zaproponowanymi w ISO 11666 dla badań konwencjonalnych. Dla złączy o grubości $8 \mathrm{~mm} \leq \mathrm{t}<15 \mathrm{~mm}$ wskazania są podzielone na dwie grupy, uzależnione od ich długości I $(\mathrm{I} \leq \mathrm{t}$ oraz $\mathrm{I}>\mathrm{t}$ ). W przypadku złączy o grubości $15 \mathrm{~mm} \leq \mathrm{t}<100 \mathrm{~mm}$ wskazania są podzielone na trzy grupy $(I \leq 0,5 t, 0,5 t<I \leq t$, I > t). O akceptowalności poszczególnych wskazań decyduje dopuszczalny poziom amplitudy przyjęty dla danej grupy wskazań. Zostanie on przedstawiony na przykładzie poziomu akceptacji 2, techniki 1 nastawiania poziomu odniesienia i zakresu grubości $15 \mathrm{~mm} \leq \mathrm{t}<100 \mathrm{~mm}$. Wskazania o długości $I \leq 0,5$ t są akceptowalne do amplitudy równej $\mathrm{H}_{0}$, wskazania o długości 0,5t < I $\leq \mathrm{t}$ są akceptowalne do amplitudy równej $\mathrm{H}_{0}-6 \mathrm{~dB}$, natomiast wskazania o długości I > t są akceptowalne do amplitudy równej $\mathrm{H}_{0}-10 \mathrm{~dB}$.

Wszystkie wskazania akceptowalne, których amplituda przekracza poziomy rejestracji a długość jest większa od wartości granicznej (tzn. t dla zakresu grubości $8 \mathrm{~mm}$ $\leq \mathrm{t}<15 \mathrm{~mm}$ oraz $\mathrm{t} / 2$ lub $20 \mathrm{~mm}$ dla grubości $\mathrm{t} \geq 15 \mathrm{~mm}$ ) powinny zostać poddane dalszym badaniom, z użyciem innego kąta padania wiązki lub techniki tandem. Wymaganie to, zaczerpnięte bezpośrednio z normy ISO 11666, jest bardzo kłopotliwe w przypadku badań automatycznych, w których ocena wskazań następuje niezależnie od skanowania złączy. Powoduje to potrzebę powrotu na miejsce wykonywania badań, ponownego zamontowania sprzętu (np. na rurociągu) i powtórnego badania złączy przy zastosowaniu alternatywnego planu skanowania (tzw. scan plan, gwarantujący inne kąty padania wiązki na wykryte wcześniej wskazanie). Z tego względu znacznie wygodniejszym i bardziej skutecznym sposobem wykonania badania uzupełniającego byłoby zastosowanie manualnych badań phased array na danym odcinku złącza, które umożliwiałoby uzyskanie maksymalnej amplitudy wskazania. Niestety tego rodzaju badanie nie zostało opisane w żadnej z norm EN lub ISO, 
stąd dodatkowe trudności w jego wdrożeniu. Alternatywą są konwencjonalne badania ultradźwiękowe, które jednakże ze względu na ograniczony wybór kątów głowic mogą w ogóle nie wykryć danego wskazania.

Wskazania akceptowalne leżące w bliskiej odległości od siebie powinny zostać zgrupowane dla celów oceny wówczas, jeśli są spełnione wszystkie trzy warunki:

- odległość pomiędzy wskazaniami w kierunku długości złącza jest mniejsza niż dwukrotna długość dłuższego wskazania,

- odległość pomiędzy wskazaniami w kierunku szerokości złącza jest mniejsza od połowy grubości, ale nie większa niż $10 \mathrm{~mm}$,

- odległość pomiędzy wskazaniami w kierunku grubości złącza jest mniejsza od połowy grubości, ale nie większa niż $10 \mathrm{~mm}$.
W przypadku, gdy wszystkie wskazania (zarówno pojedyncze, jak i zgrupowane) są akceptowalne, wówczas o akceptacji całego złącza decyduje skumulowana długość wszystkich indywidualnie akceptowalnych wskazań na odcinku o długości $I_{w}=6 t$. Warto zauważyć, że $-\mathrm{w}$ odróżnieniu od normy ISO 11666 - długość odcinka $I_{w}$ jest określona powyższym wzorem w całym zakresie grubości (w przywołanej normie wzór ten obowiązywał wyłącznie dla złączy o grubości poniżej $15 \mathrm{~mm}$ ). Na przykład, dla poziomu akceptacji 2 akceptowalna skumulowana długość wskazań na odcinku $I_{w}$ wynosi $20 \%$ długości tego odcinka.

\section{Analiza i wnioski}

Ukazanie się normy PN-EN ISO 19285 zawierającej kryteria akceptacji dla złączy spawanych badanych przy użyciu techniki phased array jest znacznym ułatwieniem w procesie wdrażania tych badań w polskiej praktyce przemysłowej. Powinno ono skutkować znacznym przyspieszeniem procesu zastępowania konwencjonalnych badań ultradźwiękowych innowacyjną i znacznie bardziej wiarygodną techniką phased array. W pierwszej kolejności należy wprowadzać technikę phased array do badań najbardziej odpowiedzialnych złączy tam, gdzie dąży się do wykrycia wszystkich nieakceptowanych nieciągłości i z tego względu stosowany jest 100\% zakres badań. Wówczas możliwość udokumentowania przeprowadzonej kontroli ultradźwiękowej w postaci zachowania plików danych z defektoskopu, a także możliwość wykonania powtórnej oceny wyników ma niebagatelne znaczenie. W przypadku długich złączy doczołowych, w których można zastosować większe skanery, optymalnym rozwiązaniem jest uzupełnienie badań phased array realizowaną symultanicznie techniką TOFD, która w niewielkim stopniu zwiększa pracochłonność badania, a jednocześnie ogranicza do minimum możliwość niewykrycia nieciągłości [3,4].

Pozytywny fakt, jakim jest pojawienie się PN-EN ISO 19285 nie może jednak przysłonić pewnych nasuwających się wątpliwości, związanych z przyjętą konstrukcją normy, będącej scaleniem norm ISO 15626 oraz ISO 11666 dotyczących kryteriów akceptacji w badaniach techniką TOFD oraz konwencjonalnych badaniach UT. Kryteria te zostały opracowane dla zupełnie odmiennych technik ultradźwiękowych, bazujących na innych sposobach detekcji wskazań (dyfrakcja w TOFD, odbicie z najwyższą możliwą do uzyskania amplitudą wskazania w konwencjonalnych badaniach ultradźwiękowych), jak i środkach wykorzystanych do tej detekcji (głowice szerokopasmowe o wysokich częstotliwościach i bardzo małych przetwornikach w TOFD, głowice konwencjonalne i wykorzystanie ich wiązki poza polem bliskim głowicy w warunkach braku silnych wahań ciśnienia akustycznego w UT). Stąd też przeniesienie kryteriów wymiarowych z TOFD oraz amplitudowych z UT do badań phased array jako kryteriów równoważnych może prowadzić do znaczących różnic w ocenie złączy, zależnej od techniki badania, przyjętych kryteriów (wymiarowych, amplitudowych) czy też zastosowanego wariantu badań PAUT (skan sektorowy, liniowy) oraz jego parametrów (zakres kątowy, pozycja głowicy, wielkość apertury, ogniskowanie itd.). Aby zobrazować możliwe skutki takiego systemu oceny na rysunku 4 i 5 przedstawiono wyniki badania fragmentu złącza o grubości 15 mm i kącie ukosowania $25^{\circ}$, wykonanego przy użyciu skanu sektorowego typu compound i techniki 1 nastawiania poziomu odniesienia (DAC, $\varnothing 3 \mathrm{~mm}$ ). Badania zostały wykonane przy identycznych ustawieniach wiązki i nastawach czułości. Jedyną różnicą było usytuowanie głowicy; odległość czoła głowicy od osi spoiny w pierwszym badaniu wynosiła 16 mm, natomiast w drugim $33 \mathrm{~mm}$. W pierwszym badaniu kąt wiązki padającej na przyklejenie wynosi $57^{\circ}$ i umożliwia uzyskanie maksymalnej amplitudy równej $\mathrm{H}_{0}-12 \mathrm{~dB}$. W drugim przypadku przyklejenie jest wykrywane wiązką o kącie $65^{\circ}$, zapewniającą prostopadłe

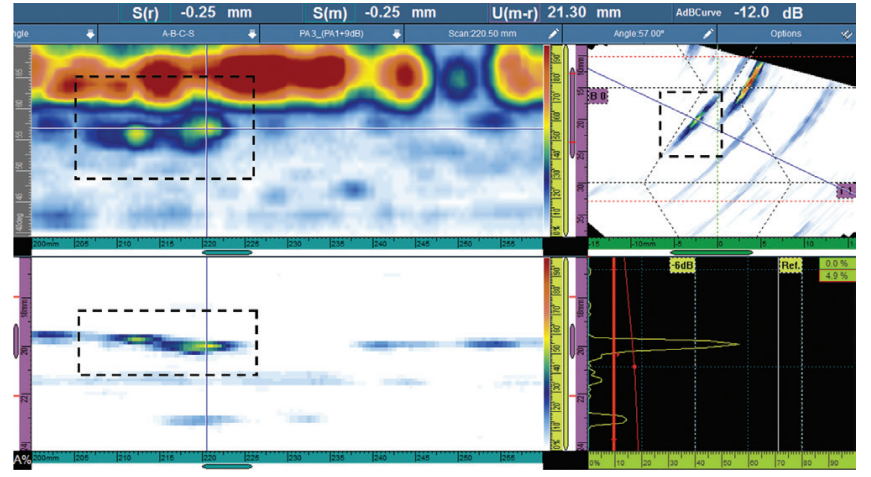

Rys. 4. Wskazanie przyklejenia brzegowego o maksymalnej amplitudzie równej $\mathrm{H}_{0}-12,0 \mathrm{~dB}$ uzyskanej wiązką o kącie $57^{\circ}$ (skan sektorowy typu compound, odległość głowicy od osi spoiny $16 \mathrm{~mm}$ ) Fig. 4. Indication of edge sticking with a maximum amplitude equal to $\mathrm{H}_{0}-12.0 \mathrm{~dB}$ obtained with a beam of $57^{\circ}$ angle (sectoral scan of compound type, distance of the head from the axis of the weld $16 \mathrm{~mm}$ )

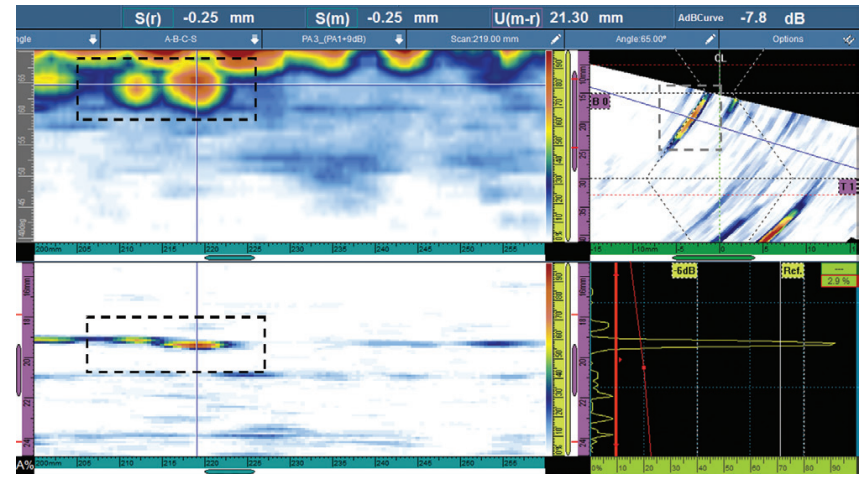

Rys. 5. Wskazanie przyklejenia brzegowego z rysunku 4 o maksymalnej amplitudzie równej $\mathrm{H}_{0}-7,8 \mathrm{~dB}$ uzyskanej wiązką o kącie $65^{\circ}$ (skan sektorowy typu compound, odległość głowicy od osi spoiny $33 \mathrm{~mm}$ ) Fig. 5. Indication of edge sticking from figure 4 with maximum amplitude equal to $\mathrm{H}_{0}-7.8 \mathrm{~dB}$ obtained with a beam of $65^{\circ}$ angle (sectoral scan of compound type, distance of the head from the axis of the weld $33 \mathrm{~mm}$ ) 
padanie wiązki na ściankę rowka spawalniczego, stąd też wyższa amplituda wskazania wynosząca $\mathrm{H}_{0}-7,8 \mathrm{~dB}$. Stąd wniosek, że przy ocenie bazującej na amplitudzie i długości wskazań nawet niewielkie zmiany kąta padania wiązki na nieciągłość wynikające między innymi z odległości głowicy od osi spoiny mogą prowadzić do kilkudecybelowych zmian amplitudy, która może diametralnie zmienić ocenę danego wskazania (akceptacja / brak akceptacji lub rejestracja / brak rejestracji).

Przykład ten obrazuje fakt, że zaczerpnięcie kryteriów akceptacji z badań konwencjonalnych nie jest dobrym rozwiązaniem w odniesieniu do badań phased array z użyciem skanu sektorowego przy zachowaniu stałej odległości głowicy od osi spoiny. Stosowanie kryteriów amplitudowych jest zasadne w przypadku:

- manualnych badań phased array z użyciem skanu sektorowego oraz badań automatycznych z zastosowaniem mechanicznego skanowania rastrowego, w których możliwe jest, poprzez odpowiednie odsunięcie głowicy od spoiny, znalezienie maksymalnej amplitudy wskazania,

- badań phased array z użyciem skanu liniowego, z kątem dopasowanym do kąta ukosowania spoiny, adekwatnie do badań konwencjonalnych,

- badań phased array, w których stosowane są ustalone kąty wprowadzenia wiązki, kierowane w ściśle określone obszary spoiny a czułość poszczególnych wiązek skalowana jest niezależnie.

W tych przypadkach wyniki badań phased array będą porównywalne a amplitudy wskazań będą zbliżone do tych, które uzyskiwane byłyby w badaniach konwencjonalnych.

W pozostałych przypadkach, takich jak najbardziej rozpowszechnione i najkorzystniejsze z praktycznego punktu widzenia badanie z użyciem skanu sektorowego przy stałej odległości głowicy od osi spoiny, może dochodzić do znaczących rozbieżności między oceną tych samych fragmentów złączy spawanych. Ponadto może wystąpić silne zróżnicowanie oceny nieciągłości, w szczególności płaskich, w zależności od ich usytuowania na głębokości złącza. W opinii autorów, w takich przypadkach powinny być stosowane kryteria oparte na długości i wysokości wskazań, z odpowiednio dopasowanym poziomem oceny. Zastosowanie tutaj poziomów oceny z badań konwencjonalnych prowadziłoby do pominięcia wielu wyraźnie widocznych, łatwych do interpretacji wskazań o niskiej amplitudzie. Poprawnie określony poziom oceny powinien być dopasowany do amplitudy wskazań dyfrakcyjnych, zwłaszcza w przypadku badania grubych złączy, dla których niemożliwe jest zapewnienie korzystnego, prostopadłego padania wiązek na powierzchnię ścianki rowka spawalniczego, w pobliżu której występuje największa ilość najniebezpieczniejszych nieciągłości (przyklejenia brzegowe oraz pęknięcia).

W PN-EN ISO 19285 niestety nie sprecyzowano warunków, przy zachowaniu których mogą być stosowane kryteria wymiarowe, czy też amplitudowe. Całkowity ciężar doboru parametrów badania oraz wyboru stosowanych kryteriów akceptacji został zatem przeniesiony na procedurę badania, wymaganą zgodnie z PN-EN ISO 13588 we wszystkich poziomach badania (A, B, C i D). Obowiązek prawidłowego zaplanowania strategii badania wraz z doborem kryteriów akceptacji oraz wykazaniem ich skuteczności spoczywa więc na personelu III stopnia, który opracowuje procedury badań techniką phased array.

\section{Literatura}

[1] Kaczmarek R.: Problematyka wskazań od geometrii w konwencjonalnych badaniach ultradźwiękowych oraz badaniach Phased Array, Biuletyn Instytutu Spawalnictwa, nr 2, 2017.

[2] Mackiewicz S.: Badania złączy spawanych techniką phased array w świetle wymagań PN-EN ISO 13588, Przegląd Spawalnictwa, Vol. 87, nr 12, 2015.

[3] Kaczmarek R., Kaczmarek K., Słania J.: Zalety symultanicznych badań ultradźwiękowych techniką Phased Array i TOFD złączy spawanych, Przegląd Spawalnictwa, Vol. 89, nr 4, 2017.

[4] Kaczmarek R., Kaczmarek K., Słania J., Krawczyk R.: Wykonywanie badań ultradźwiękowych techniką TOFD w aspekcie wymagań norm przedmiotowych, Biuletyn Instytutu Spawalnictwa, nr 4, 2016.

[5] PN-EN ISO 13588 Badania nieniszczące spoin - Badania ultradźwiękowe - Stosowanie technologii zautomatyzowanej głowicy mozaikowej

[6] PN-EN ISO 19285 Badania nieniszczące spoin - Badania ultradźwiękowe techniką głowicy mozaikowej (PAUT) - Kryteria akceptacji

[7] PN-EN ISO 15626 Badanie nieniszczące spoin - Technika czasu przejścia wiązki dyfrakcyjnej (TOFD) - Poziomy akceptacji

[8] PN-EN ISO 11666 Badania nieniszczące spoin - Badania ultradźwiękowe - Poziomy akceptacji 